INTERNATIONAL JOURNAL OF MULTIDISCIPLINARY RESEARCH AND ANALYSis

ISSN(print): 2643-9840, ISSN(online): 2643-9875

Volume 05 Issue 01 January 2022

DOI: 10.47191/ijmra/v5-i1-20, Impact Factor: 6.072

Page No.- 155-159

\title{
Development of Scientific-Based Introduction Practicum Guidelines and Laboratory Techniques to Improve Student's Skills
}

\author{
Harizqi Azri ${ }^{1}$, Yuni Ahda ${ }^{2}$ \\ ${ }^{1}$ Master of Biology Education, FMIPA, Padang State University, Indonesia. \\ ${ }^{2}$ Postgraduate Biology Education, FMIPA, Padang State University, Indonesia.
}

\begin{abstract}
This study aims to determine the practicality of developing scientific-based introduction practicum guides and laboratory techniques. This type of research is development research using the Plomp Model. The sample of this study were students of Biology Education STKIP PGRI West Sumatra. The instrument used is a practicality questionnaire compiled using a Likert scale with five answer options. The data were processed using the percentage formula and categorised by the level of practicality obtained and then analysed descriptively. The practical test results showed that the practical guide was very practical (93.4\%) in the small group. Then proceed with field testing. The field test results also obtained very practical results with a value of $90.2 \%$ from lecturers and $81.7 \%$ from students. The introduction of scientific-based laboratory techniques and introduction practicum can provide convenience in terms of use, efficiency of use, and benefits for students and lecturers in carrying out practical activities.
\end{abstract}

KEYWORDS: Practicum Guidelines, Introduction And Laboratory Techniques, Scientific Approach, Practicality

\section{INTRODUCTION}

At universities with biology education study programs, introduction courses and laboratory engineering are mandatory subjects. This course introduces equipment and how to use tools, manufacture of reagents for biology practicum activities, administration and management of biological laboratories, study the hazards of working in laboratories, etc. Introduction courses and biology laboratory techniques equip graduates to acquire basic knowledge to manage laboratories so that teachers can carry out practical activities in the laboratory.

Difficulties in sharpening student skills in the use of tools and materials, sample preservation, and first aid in work accidents can be due to several reasons, one of which is that students memorise the material they find and are less able to interpret laboratory engineering concepts to be implemented in practical and practical activities-resulting in their inability to relate this knowledge to the latest situations and conditions. One of the impacts is knowing the names of tools and materials but not knowing their shape, nature, function and maintenance. This inability can also impact other courses in the following semester where students should have been skilled in and able to interpret the observations, but this did not happen.

Difficulties will also impact if the availability of tools in the laboratory is lacking, so it will cause unfavourable student activities in practical learning. The same thing was conveyed by Thalib et al. (2020) when practicum activities in the field were active due to interactions between friends and supported by laboratory equipment. In this process, some students were less active because there was nothing due to the limitations of the existing tools.

In practical activities, it is also important to evaluate student performance related to the work skills on the practical material carried out. So far, the practicum guide provides an assessment of the understanding of the practicum material, and it is rare to find a rubric for assessing student performance. At the time of the practicum exam, there was a performance test, but the assessment was always on the final result, not on the process. So it is not known the level of student skills in working in the laboratory. Also, the lecturer has not evaluated what part of the student's inability to work in the laboratory.

Usman et al. (2014) say that the process of implementing scientific activities or student practicums requires a separate assessment so that it can provide comprehensive information on student learning outcomes, where the object used as an assessment is psychomotor and cognitive abilities. However, the same constraints stated by Usman et al. (2014), where the majority 


\section{Development of Scientific-Based Introduction Practicum Guidelines and Laboratory Techniques to Improve Student's Skills}

of teachers in the lab do not use a rubric assessing performance assessment lab, just based on everyday experience of the work of students and based on whether or not to see the report and in the report.

Become from this problem, and it is important to develop a practicum guide that can train and assess student skills, such as selecting, operating, and maintaining tools and materials and working safely, efficiently with chemicals. In addition, a scientific approach is also needed in the practical guidebook because working in a laboratory requires students' ability to think scientifically. Ghozali (2017) states the scientific learning approach of students will be able to develop knowledge, thinking skills, and psychomotor skills through direct/indirect interaction with designed learning resources. With this approach, student learning achievement can increase to achieve the criteria for achieving educational goals.

\section{RESEARCH METHOD}

This research is a type of development research or R\&D using the Plomp Model. This research sample is a student of Biology Education STKIP PGRI West Sumatra. The instrument used is a practical questionnaire arranged using a Likert scale with five answer options.

Before field testing, practicum guides are first tested in small groups to find out the feasibility of the display of products developed. In the field test, practical instruments are given to students and lecturers (users) after practicum activities to determine the ease of use of practicum guides in practicum activities.

The results obtained are recapitulated and then tabulated according to the assessed indicators and the number of assessed users. Data is processed using percentage formulas and categorised by the level of practicality obtained and then analysed descriptively.

Practical Values $=(S P: S M) \times 100 \%$

Description:

$\mathrm{SP}=$ Acquisition Score

$\mathrm{SM}=$ Maximum Score

Table. 1 Practicality Criteria Guide Practicum Introduction and Scientific-Based Laboratory Techniques

\begin{tabular}{ll}
\hline Practical Values & Practicality Criteria \\
\hline $81-100 \%$ & Very Practical \\
$61-80 \%$ & Practical \\
$41-60 \%$ & Quite Practical \\
$21-40 \%$ & Less Practical \\
$0-20 \%$ & Impractical
\end{tabular}

(Source: Riduwan, 2012)

\section{RESULT AND DISCUSSION}

\section{RESULT}

a. Practicum Guide Practicality Results

Small group trials were trial to seven students. The aspects assessed are images and colours, type and size of letters, layout, presentation of material, and the language used of the five aspects obtained an average value of $93.4 \%$ with very practical criteria. Details of the results of the small group trial are in Table 2.

Table 2. Results of Practical Tests for Small Groups Experimental Guidance on Introduction to Scientific-Based Laboratory Techniques by Students

\begin{tabular}{|c|c|c|c|c|c|}
\hline \multirow{2}{*}{ No } & \multirow{2}{*}{ Rated Indicators } & \multicolumn{2}{|c|}{ Amount } & \multirow{2}{*}{ Average } & \multirow{2}{*}{ Category } \\
\hline & & SP & SM & & \\
\hline 1 & Display images and colours & 66 & 70 & $94.3 \%$ & Very Practical \\
\hline 2 & Font type and size & 32 & 35 & $91.4 \%$ & Very Practical \\
\hline 3 & Layout & 32 & 35 & $91.4 \%$ & Very Practical \\
\hline 4 & Material presentation & 67 & 70 & $95.7 \%$ & Very Practical \\
\hline 5 & Language & 33 & 35 & $94.3 \%$ & Very Practical \\
\hline \multicolumn{2}{|c|}{ Overall Average } & & & $93.4 \%$ & Very Practical \\
\hline
\end{tabular}




\section{Development of Scientific-Based Introduction Practicum Guidelines and Laboratory Techniques to Improve Student's Skills}

After the practicum guide trials, field tests on lecturers and students. Questionnaires were given to lecturers and students, aiming to find out the ease of use of the developed practicum guide. The aspects assessed are ease of use, efficiency of use, and the benefits of practicum claimants. Details of the practicality test results are in Tables 3 and 4.

Table 3. Results of Practical Testing of Introduction to Scientific-Based Laboratory Techniques by Lecturers

\begin{tabular}{llllll}
\hline \multirow{2}{*}{ No } & \multirow{2}{*}{ Rated Indicators } & \multicolumn{2}{c}{ Amount } & \multirow{2}{*}{ Average } & \multirow{2}{*}{ Category } \\
\cline { 3 - 4 } & & SP & SM & & \\
\hline 1 & Ease of use & 201 & 220 & $91.4 \%$ & Very Practical \\
2 & Interpretation & 18 & 208 & $90 \%$ & Very Practical \\
3 & Efficient use of practical guide & 88 & 100 & $88 \%$ & Very Practical \\
4 & Benefit & 128 & 140 & $91.4 \%$ & Very Practical \\
\hline \multicolumn{2}{l}{ Overall Average } & & & $90.2 \%$ & Very Practical \\
\hline
\end{tabular}

Description; SP: gain score, SM: maximum score.

The practical aspects of practicum guides assessed by students are ease of use, the efficiency of use, and the benefits of practicum claimants. The results can see in Table 4

Table 4. Results of Practical Testing of Introduction to Scientific-Based Laboratory Techniques by Students of the Biology Education Study Program, STKIP PGRI, West Sumatra

\begin{tabular}{llllll}
\hline \multirow{2}{*}{ No } & \multirow{2}{*}{ Rated Indicators } & \multicolumn{2}{c}{ Amount } & \multirow{2}{*}{ Average } & \multirow{2}{*}{ Category } \\
\cline { 3 - 4 } & SP & SM & & \\
\hline 1 & Ease of using the practical guide & 425 & 525 & $81 \%$ & Very Practical \\
2 & Efficient use of practical guide & 122 & 150 & $81.3 \%$ & Very Practical \\
3 & Benefit & 186 & 225 & $82.7 \%$ & Very Practical \\
\hline Overall Average & & & $81.7 \%$ & Very Practical \\
\hline
\end{tabular}

Description; SP: gain score, SM: maximum score.

\section{DISCUSSION}

Introduction and Laboratory Techniques practicum guide developed using a scientific approach and designed as needed to be used by subject lecturers and biology students. The development of this practicum guide has adapted to the syllabus for Introduction to Laboratory Engineering and scientific activities such as (1) orientation, given discourse, (2) formulating problems, (3) formulating hypotheses, (4) collecting data, (5) testing hypotheses, and (6) formulate conclusions.

Development begins with conducting initial investigations in curriculum analysis, student analysis and guiding analysis. The analysis results carried out during the initial investigation were used as material for consideration in designing the prototype, namely the content of the material, the form of activities and the practicum learning approach used in the Introduction and Laboratory Engineering practicum guide. Following Zural and Susanti (2017) that from the results of curriculum analysis which is one of the initial investigative activities, learning objectives formulated and the main points of learning materials systematically arranged so that learning is more directed and organised.

From the initial investigation results, a prototype worked on a practicum guide to the needs of students. After that, the prototype will self-evaluate with a check sheet to find out the errors that appeared. Then a feasibility test is carried out on the product, which is given to the validator. After that, a one-to-one trial was carried out on four students and continued with a small group trial for seven students.

Practicality questionnaires were given to seven small group students to determine whether the scientific-based introduction and laboratory technique guide still had deficiencies before the next stage, namely the field test. Plomp (2013: 35) states to determine the practicality and effectiveness of the products developed, and small group trials were conducted. The small group results obtained get a positive response with a very practical category. Students feel that the practicum guide is easy to use because the instructions in each activity can also optimise student work in the implementation of practicum. Students can raise bee practicality because all students in the small group can interpret every scientific activity and practicum work properly and systematically and have the same equivalence from every student who reads it. So that in practicum activities, students are found to be enthusiastic in collecting practicum data. 


\section{Development of Scientific-Based Introduction Practicum Guidelines and Laboratory Techniques to Improve Student's Skills}

In line with the opinion of Alfiriani and Hutabri (2017), that practicality refers to the condition of teaching materials that can be easily used by students so that the learning carried out is meaningful, interesting, fun, and useful for students, and can increase creativity in learning and have a degree of effectiveness. On the learning outcomes of these students. Following the opinion of Alfiriani and Hutabri (2017), the product test to the next stage.

The practical test of scientific-based Introduction and Laboratory Techniques practicum guide aims to determine the lecturer's response to the developed product. The practical results of the Introduction and Laboratory Techniques practicum guide given by the lecturer received a positive response in the very practical category. Positive response in the very practical category shows that the Introduction and Scientific-Based Laboratory Engineering practicum guide has convenience for lecturers including; make it easier for lecturers to guide, organise work and assisting lecturers in developing students' creativity, activities and scientific attitudes. The practical guide is also easy to interpret because it has prepared in informative language.

From these results, it is similar to that expressed by Plomp (2013: 29) that a developed media is said to be practical if the media can be used easily by users (lecturers, practicum supervisors and students) in learning. Nurhadi et al. (2018) state learning media are said to be practical about the ease with which the user uses the media, in which the purpose of the practicum is adjusted to student achievement, clear and systematic scientific steps, guidance for students in carrying out scientific steps, study the theory with picture shows that make the practicum easier for students to understand.

Introductory Guide to Scientific-Based Laboratory Techniques is very efficient to use by both lecturers and students because this design is easy to use with columns for writing reports of results, data analysis and conclusions, and have been equipped with columns for scientific steps. The column can be used directly by students during practicum activities to fill in questions when formulating problems, fill in answers when formulating hypotheses, write results and analyse data obtained and make conclusions. So that the scientific step columns and the lab results report columns can help lecturers determine the level of student understanding of the material is practised.

From the results of interviews conducted by Susilo et al. (2015) to students regarding practicum reports, some students had difficulties writing practicum reports. The student stated that the systematics of writing and the boundaries between the report sections were not clear. From this report, student requests more detailed demands and what aspects should in the practicum report. Some request indicates that students still need more intensive guidance in writing reports. So that students need guidance as an alternative to improve students' abilities in writing practicum reports. So referring to the problem of Susilo et al. (2015), the Practical Guide to Introduction and Scientific-Based Laboratory Techniques has prepared well every data written by students in the practicum guide as a form of report that must create. Practicum guide, in addition to making it easier for lecturers to check practicum reports, also makes it easier for students to make practicum reports.

In the practicum guide assessment sheet, a performance assessment helps lecturers determine the level of student work skills acquisition in the laboratory. Performance assessment also helps lecturers to find out the difficulties experienced by students in collecting practicum data. Fitriyani et al. (2013) also agreed, where the assessment for work affects students more on the material provided compared to the assessment of work results. Because with performance assessments, teachers will know more about the ability of students to understand the products they have produced. Besides that performance assessments make students play a more active role in the learning process.

\section{CONCLUSION}

The study results concluded that developing a scientific-based introduction to laboratory guide and scientific-based biology laboratory technique for students is very practical and can be tested further to the effectiveness stage.

\section{ACKNOWLEDGEMENT}

The researcher would like to thank Dr Syamzurizal M. Biomed and Mr Prof. Dr Abdul Razak, M.Si, for providing input and suggestions for this research.

\section{REFERENCES}

1) Thalib, I., Ningsih, K., dan Wahyuni, S., E. 2010. Pengaruh Pendekatan Saintifik Terhadap Hasil Belajar dan Retensi Siswa Materi Ekosistem Kelas X, Jurnal Pendidikan dan Pembelajaran Khatulistiwa,. Vol 9 (1).

2) Ghozali, I. 2017. Pendekatan Scientific Learning Dalam Meningkatkan Prestasi Belajar Siswa. Jurnal Pedagogik, 04(01): 113. https://ejournal.unuja.ac.id/index. php/pedagogik/article/download/5/5

3) Usman U., Herman H., dan Yusuf, A.M.. 2014. Pengembangan Perangkat Penilaian Kinerja Praktikum Fisika Pada Peserta Didik SMP Unismuh Makassar. Jurnal Sains dan Pendidikan Fisika, 10(3): 274-284. DOI: 10.35580/jspf.v10i3.965 


\section{Development of Scientific-Based Introduction Practicum Guidelines and Laboratory Techniques to Improve Student's Skills}

4) Alfiriani, A., dan Hutabri, E. 2017. Kepraktisan Dan Keefektifan Modul Pembelajaran Bilingual Berbasis Komputer. Jurnal Kependidikan, 1(1); 12-23.

5) Riduwan. 2006. Belajar Mudah Penelitian untuk Guru, Karyawan dan Peneliti Pemula. Bandung: Alfabeta

6) Zural, MM., dan Silvi, S. 2017. Curriculum Needs Analysis In The Development Of Heredity Teaching Media At MAN 2 Padang. Prosiding Semnas Bio-1, 2(1); 372-380.

7) Plomp, T dan N, Nieveen. 2013. Educational Design Research: An Introduction. Enschede: Netherlands Institute for Curriculum Development

8) Nurhadi, N., Zural, MM., Zubir, Y., dan Rosba, E. 2018. The Development Test of Practical Work Module of Animal Structure Using Modified Free Inquiry. Journal of Physics: Conference Series. 1108. 012011. 10.1088/1742-6596/1108/1/012011.

9) Susilo, A., Huda, N., Putra, AAS., dan Ludivica E.S. 2015. Evaluasi Penyelenggaraan Praktikum Mandiri Program Studi Agribisnis Universitas Terbuka. Jurnal Pendidikan Terbuka dan Jarak Jauh, 16 (1): 58-67.

10) Fitriyani, Jaenudin, R., dan Fatimah, S. 2013. Pengaruh Penilaian Unjuk Kerja Terhadap Sikap Peserta Didik Terhadap Mata Pelajaran Ekonomi di SMA Srijaya Negara Palembang. Criksetra; Jurnal Pendidikan \& Kajian Sejarah, 3(4): 3404.23-3404.28. 